\title{
Beta-cell mass and proliferation following late fetal and early postnatal malnutrition in the rat
}

\author{
A. Garofano, P. Czernichow, B. Bréant \\ INSERM U 457, Hôpital Robert Debré, Paris, France
}

\begin{abstract}
Summary We have recently shown that maternal food restriction during late pregnancy in rats decreased beta-cell mass in the offspring at birth, without altering beta-cell proliferation. The aim of the present work was to determine: 1) whether sustained maternal undernutrition until weaning ( $\mathrm{R}$ group) more dramatically alters beta-cell mass in the offspring and if normal food supply from weaning until adulthood could reverse the deleterious effects and; 2) if altered beta-cell proliferation was responsible for the decreased beta-cell mass. Beta-cell fraction and proliferative capacity were determined during the suckling period and at adult age after ad libitum feeding from weaning in the $\mathrm{R}$ animals and in agematched controls (C group). At day 21, the offspring born and nursed by food-restricted mothers $(\mathrm{R}$ animals) showed a $66 \%$ reduction in beta-cell mass and number, which did not increase from birth to weaning, although beta-cell proliferation remained normal. At 3 months of age, $\mathrm{R}$ animals had $35 \%$ de-
\end{abstract}

creased beta-cell fraction, with a $50 \%$ decrease in the head of the pancreas. In that area, beta-cell proliferation was similar to that of the controls. In the tail of the pancreas, beta-cell fraction was only slightly impaired but beta-cell proliferation was increased by $37 \%$, as compared with the controls. This increase was associated with a shift in islet size distribution towards medium and large islets compared with the head of pancreas from these $\mathrm{R}$ animals. No regional variations of beta-cell fraction, proliferation or islet size distribution were observed in adult control animals. In conclusion, prolonged malnutrition until weaning impairs beta-cell development but not betacell proliferation. Subsequent re-nutrition is followed by increased beta-cell proliferation but this is insufficient to fully restore beta-cell mass. [Diabetologia (1998) 41: 1114-1120]

Keywords Beta cell, proliferation, rat, nutrition, immunohistochemistry, morphometry.
Nutrition during the perinatal period is of major importance for proper tissue development and functional maturation. Epidemiological studies in humans have recently suggested that complex metabolic dysfunctions during adulthood, such as glucose intolerance or insulin resistance, could originate from in utero malnutrition [1-3]. Experimental animal models

Received: 16 February 1998 and in revised form: 20 April 1998

Corresponding author: Dr B. Bréant, INSERM U 457, Hôpital Robert Debré, 48 boulevard Sérurier, 75019 Paris, France Abbreviations: IUGR, Intra-uterine growth retardation; BrdU, 5-bromo-2'-deoxyuridine; PBS, phosphate buffered saline. based on in utero or perinatal malnutrition can provide evidence on the structural development or functional maturation of the endocrine pancreas in response to this early insult.

Perinatal nutrition in rats influences the pancreatic islet mass; indeed the islet volume of 21-day-old rats which had been segregated at birth into small litters ( 5 per litter) has been shown to be three times that of animals nursed in large ( $>13$ animals) litters [4]. In the young rat, protein-energy restriction after weaning severely alters beta-cell mass and this impairment cannot be compensated for by normal refeeding [5]. Interestingly, an isocaloric low-protein diet given to female rats throughout pregnancy decreases islet size in the offspring at birth [6]. More re- 
cently we [7] and others [8] have shown that maternal food restriction during late pregnancy induces growth retardation and decreased beta-cell mass at days 1 [7] and 4 [8] of postnatal life. The decreased beta-cell mass observed at birth associated with a normal proliferation rate in the beta cells suggested a possible defect in cell neogenesis [7]. The first aim of the present study was to determine whether prolonged postnatal undernutrition of animals born with severe intra-uterine growth retardation would more dramatically impair beta-cell mass and to what extent these deleterious effects could be reversed by a normal food supply after weaning. The second aim was to examine the potential implication of beta-cell proliferation in this alteration. For that purpose, morphometric determinations of beta-cell fraction, size and proliferation rate were performed from birth to 3 months of age.

\section{Materials and methods}

Animals and study design. Three-month-old pregnant Wistar rats (day 12 of pregnancy) were purchased from Janvier breeding centre (Le Genêt-St. Isle, France). The animals were caged individually and had free access to tap water. All rats were fed a standard laboratory rat chow (No. 113: 22\% protein, 5\% fat, $53 \%$ carbohydrates; UAR, Villemoisson-sur-Orge, France) and assigned randomly to either the control or restricted group. Maternal food restriction (50\% of ad libitum intake) was established as described previously from day 15 of pregnancy and throughout lactation [9]. At parturition, all baby rats were weighed immediately and litter size was equalized out to eight. The neonates with severe intra-uterine growth retardation (IUGR), chosen at the 2.5th percentile (body weight $\leq$ Control weight $-2 \times$ S.D) were selected, as described previously $[8,9]$ and are referred to as $\mathrm{R}$ group. Control baby rats were not selected. Both control (C) and R offspring were fed ad libitum as from weaning. They were studied from birth until adult age (90 days postnatal).

At each time point baby rats were weighed and killed thereafter by decapitation (days 1 to 21 postnatal) or cervical dislocation. In adult animals fasted for $6 \mathrm{~h}$ blood was collected from the tail vein into heparinized tubes and glucose was immediately measured with a glucometer One touch II (Lifescan, Roissy, France) using the glucose oxidase method. After centrifugation at $4{ }^{\circ} \mathrm{C}$, plasma samples were stored at $-20^{\circ} \mathrm{C}$ until assayed for insulin which was measured by RIA using monoiodinated porcine insulin as tracer (Sorin Biomedica, Saluggia, Italy), guinea pig anti-insulin antibody (provided by C. Van Schravendijk, Brussels, Belgium) and purified rat insulin as standard (Novo Nordisk, Boulogne, France).

These studies were approved by the French animal ethics committee.

Tissue processing. For immunohistochemistry, five animals of each group were analysed at days 1, 7, 21 and at 3 months of age (90 days postnatal). One hour before killing, the animals were i.p. injected with a dose of $50 \mathrm{mg} / \mathrm{kg}$ body weight of 5bromo- 2 '-deoxyuridine (BrdU) (Sigma, LaVerpillière, France) dissolved in phosphate buffered saline (PBS) [10]. The whole pancreas was excised and its weight determined. The organ was fixed for $2 \mathrm{~h}$ in $4 \%$ paraformaldehyde-PBS (Sigma, France), successively immersed in $15 \%$ (overnight) and $30 \%(2 \mathrm{~h})$ sucrose-PBS solutions (Sigma, France), frozen under nitrogen fumes and stored at $-20^{\circ} \mathrm{C}$ until sectioned. Pancreata from adult offspring were cut into three pieces of similar weight corresponding to the head (i.e. duodenal side), the median and the tail (i.e. spleen side) portions of the pancreas, which were fixed and processed separately. Each pancreas, or piece of pancreas, was sectioned (6 $\mu \mathrm{m}$ thick) throughout its length to avoid any bias due to regional variation in islet distribution and cell composition. Every 30th section was analysed from 1-day-old, 7-day-old $\mathrm{C}$ and $\mathrm{R}$ baby rats and 21-day-old $\mathrm{R}$ weanlings; every $42 \mathrm{nd}$ section was analysed from 21-day-old $\mathrm{C}$ and from all adult pancreata. This procedure yielded five to seven sections from each pancreas (day 1 to 21) or each portion of adult pancreas. The median portion was not analysed.

Double immunohistochemistry and morphometry. After preincubation in $4 \mathrm{~N} \mathrm{HCl}$ for $10 \mathrm{~min}$ at $37^{\circ} \mathrm{C}$, the sections were double immunostained for BrdU and insulin, as described previously [7]. Proliferating cells were detected with a mouse monoclonal anti-BrdU antibody (Sigma, France) using the avidin-biotin-complex/horse radish-peroxidase method (Amersham, Les Ulis, France) and visualized with 3,3'-Diaminobenzidine (Sigma, France). Beta cells were stained with a guinea pig polyclonal anti-insulin antibody (Dako, Trappes, France) detected after incubation with an alkaline phosphatase anti-rabbit antibody (Promega, Lyon, France) and visualized in blue with Nitroblue tetrazolium (Vector, Biosys, Compiegne, France). The primary antibodies were both diluted 1:200 and simultaneously incubated for $2 \mathrm{~h}$ at $37^{\circ} \mathrm{C}$, a condition that allowed the detection of all insulinpositive cells. The possibility that beta cells present in islets remain unstained due to a putative decreased insulin content per cell in malnourished animals was verified at all studied ages by staining with a cocktail of anti-glucagon, somatostatin and PP antibodies. Beta-cell area detected from these tests was not different from that detected with anti-insulin antibodies (not shown). Beta cells were thus defined as insulin-positive cells. Controls for immunostaining consisted of ommission of the primary antibodies and these tests resulted in negative staining reactions.

Beta-cell fraction and BrdU labelling index were determined on the same sections. Computer assisted measurements were done with a Leica DMRB microscope equipped with a colour video camera connected to a Quantimet $500 \mathrm{MC}$ computer (screen magnification $\times 24$ ). The area of insulin-positive cells was measured on the entire section (final magnification $\times 120$ ). The area of the pancreatic tissue was measured similarly by phase contrast. Beta-cell fraction in the pancreas was calculated in each section as the ratio of insulin-positive area to the total tissue area of the section. Absolute beta-cell mass per pancreas was calculated as the product of mean beta-cell fraction by the corresponding pancreatic weight. Individual beta-cell area was manually measured at a final magnification of $\times 960$ after light counterstaining, in at least 100 insulin-positive cells, chosen randomly on different sections, for each group and at each time point. Total beta-cell number in the section was calculated from these measurements. Betacell labelling index was determined as the percentage of insulin-positive cells which were also positive for BrdU on the entire section (final magnification $\times 480$ ). Aggregates composed of more than 3 immunoreactive insulin cells (diameter $>25 \mu \mathrm{m}$ ) were counted on each section and expressed as number of insulin-positive aggregates (i.e. islets) per $\mathrm{cm}^{2}$. For the purpose of evaluating the distribution of islet sizes, islets were classified arbitrarily as small $(25 \mu \mathrm{m}<$ diameter $<100 \mu \mathrm{m})$, medium $(100 \mu \mathrm{m}<$ diameter $<150 \mu \mathrm{m})$ or large $(>150 \mu \mathrm{m})$. 

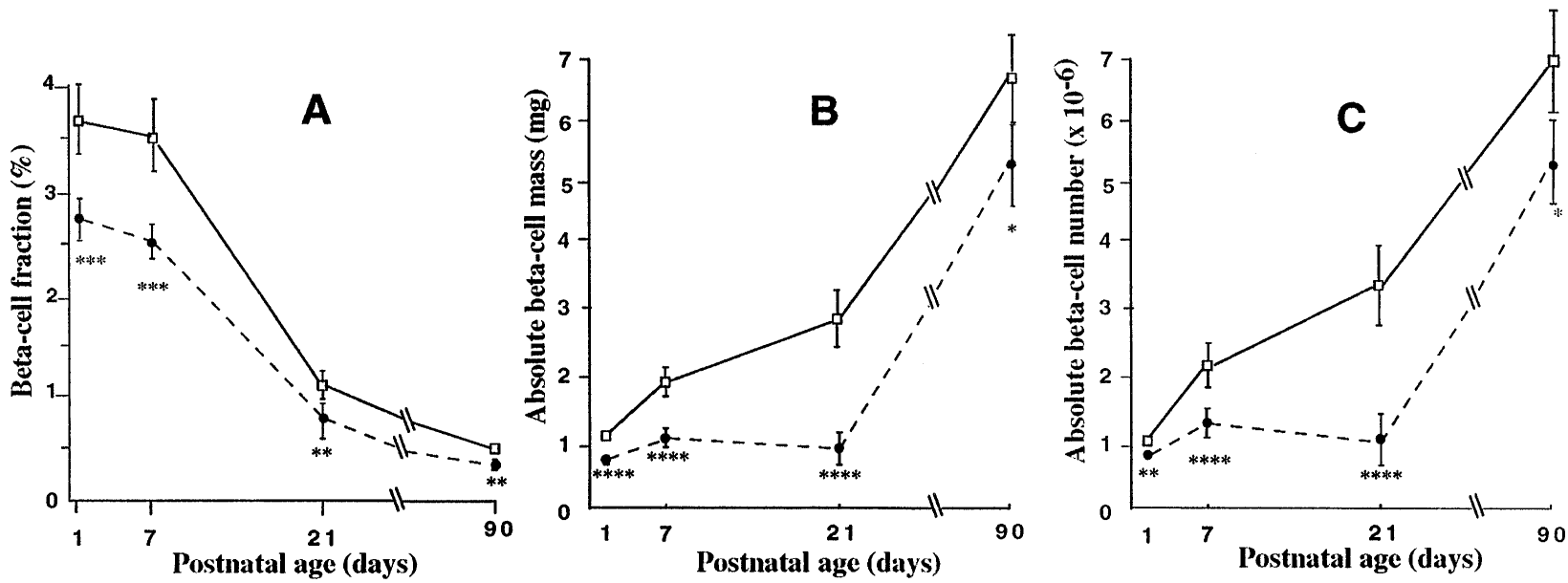

Fig.1A-C. Postnatal evolution of beta-cell fraction, beta-cell mass and beta-cell number from birth to adult age in offspring of food-restricted mothers

Mothers were food-restricted from day 15 of pregnancy until the end of lactation. Their offspring were studied at days 1,7 , 21 and $90(\bigcirc)$ and compared with control offspring $(\square)$. All animals were nourished normally after weaning (day 21 postnatal). At all stages studied, mean values of beta-cell fraction (A) were used to calculate absolute beta-cell mass (B) and absolute beta-cell number $(\mathbf{C})$, as described in Materials and methods. Values are mean \pm SD.

$* p<0.05, * * p \leq 0.01, * * * p \leq 0.001, * * * * p \leq 0.0001$, as compared with age-matched controls ( $n=5$ animals)

The data from five to seven sections per pancreas were averaged for each pancreas and thereafter for each experimental condition ( $n=5$ animals).

Estimation of the total beta-cell number per pancreas. The pancreatic density was determined using Archimede's principle. Briefly, pancreata of known weight from animals at various ages were dipped into $10 \mathrm{ml}$ of water and the volume of water displaced was measured. The pancreatic density was calculated as the ratio of the weight of the gland to this volume of water. Pancreatic density (expressed in $\mathrm{mg} / \mathrm{\mu l}$ ) was 1.05 at day $1,1.10$ at day 21 postnatal and 1.13 in adult animals. It did not differ between $\mathrm{C}$ and $\mathrm{R}$ animals (not shown). Absolute beta-cell volume was calculated as the ratio of beta-cell mass to pancreatic density, assuming a similar density for the endocrine and exocrine pancreas, as already described by others [5, 11]. Individual beta-cell volume at each time point was calculated from the individual beta-cell area with the assumption that beta cells are spherical [12-14]. These values allowed the estimation of the total beta-cell number per pancreas.

Comparison of the morphometric data from control and previously restricted adult animals were done in two ways: separately for the head and the tail of the pancreas (as described above), and also as mean values for each pancreas. Mean beta-cell fraction per adult pancreas was calculated as the ratio of the sum of insulin-positive area [(head sections 1 to $n)+($ tail sections $\left.\left.1_{1 \text { to } n}\right)\right]$ to the sum of pancreatic tissue area [(head sections $\left._{1 \text { to n }}\right)+\left(\right.$ tail sections $\left.{ }_{1 \text { to n }}\right)$ ]. From the latter values, absolute beta-cell mass per pancreas was deduced. Mean islet number $/ \mathrm{cm}^{2}$ and islet size distribution were similarly determined and averaged for each experimental group ( $n=5$ animals).
Statistical analysis. Values, expressed as mean \pm SD, were analysed by unpaired Student's $t$ test. A $p$ value less than 0.05 was considered significant.

Appendix: Mathematical formulas used to calculate the various parameters

BCF (\%): Beta-Cell Fraction = Insulin-positive area/total pancreatic area

BCM: Beta-Cell Mass per pancreas $(m g)=B C F \times$ Pancreatic weight (mg)

IBCA: Individual Beta-Cell Area $\left(\mu^{2}\right)=\Pi R^{2}$

Beta-cell number in a section = Insulin-positive area in the section/IBCA

BCLI: Beta-Cell Labelling Index $=\%$ of insulin-positive cells also positive for $\mathrm{BrdU}$

$I B C V=$ Individual Beta-Cell Volume $\left(\mu \mathrm{m}^{3}\right)==4 / 3 \Pi R^{3}$

Pancreatic density: $m g / \mu l$

BCV: Beta-Cell Volume $(\mu l)=B C M /$ Pancreatic Density

$B C N$ : Beta-Cell Number per pancreas $=B C V / I B C V$

\section{Results}

Beta-cell status during postnatal undernutrition. In restricted animals, the beta-cell fraction was reduced (25-27\%) from birth to weaning, as compared with controls (Fig. 1A). Pancreatic weight was increasingly impaired with prolonged postnatal undernutrition (Table 1). As a consequence, absolute beta-cell mass remained almost unchanged from birth to day 21 in these animals, whereas it increased threefold in control animals (Fig. 1B).

The reduction of beta-cell fraction and mass in restricted (R) baby rats could be due either to a reduction in the number of beta-cells or to a reduction of individual beta-cell size or both. These parameters were measured at each time point. A tendency towards a reduced individual beta-cell area could be observed at day 7 and 21 in $\mathrm{R}$ baby rats (Table 1 ), but was insufficient to explain the overall decrease in beta-cell mass, which is therefore likely to arise from a decreased cell number. In control animals, the estimated total beta-cell number increased progressively from 1 million cells at birth to about 3 mil- 

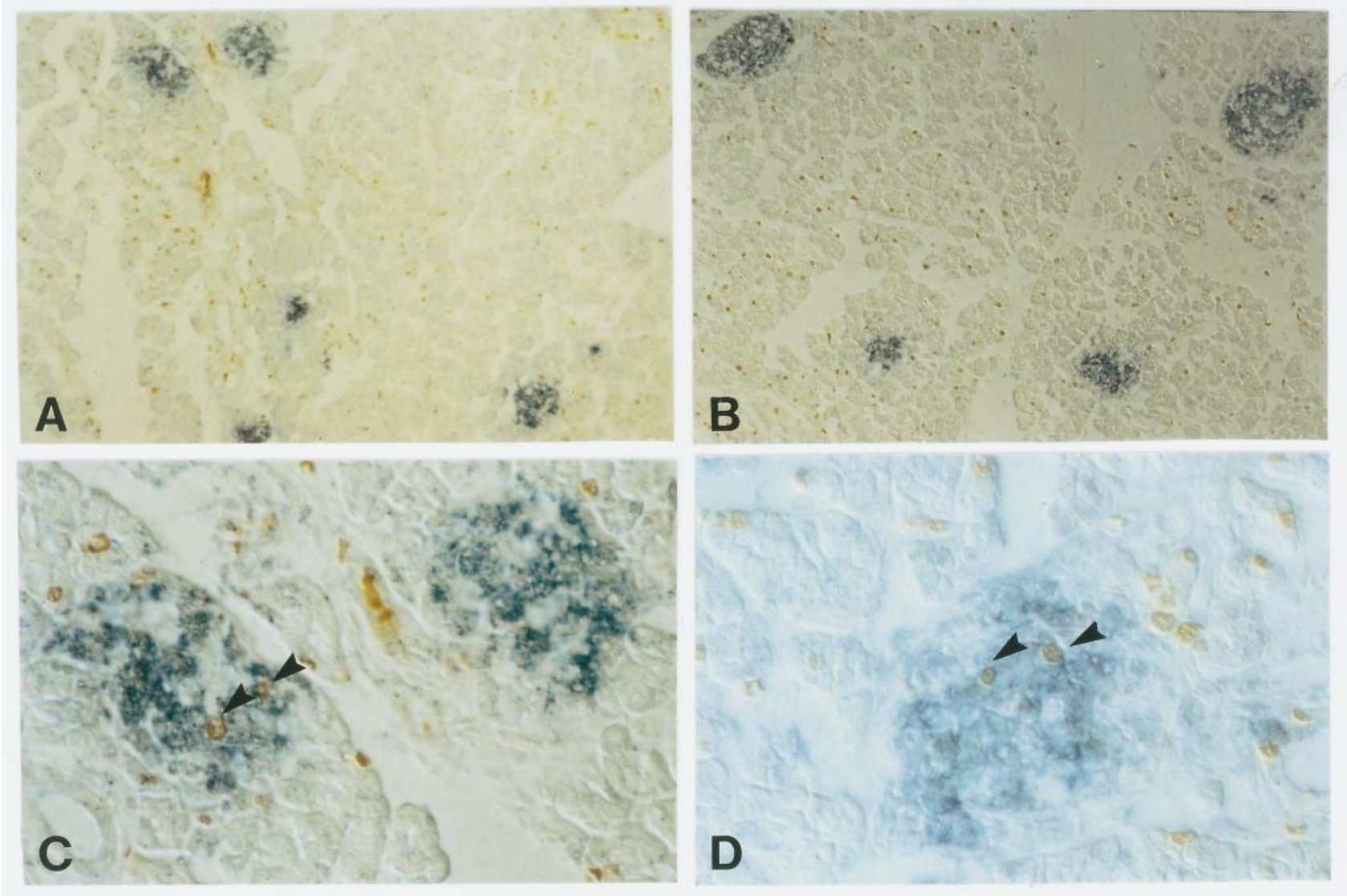

Fig. 2A-D. BrdU and insulin immunoreactive cells in pancreata from 21-day-old $\mathrm{R}$ and control animals

Immunohistochemical double staining for BrdU (brown nuclei) and insulin (blue) in pancreatic frozen sections of 21day-old control rats $(\mathbf{A}, \mathbf{C})$ or from $\mathrm{R}$ rats born to mothers food-restricted from day 15 of pregnancy through the end of lactation $(\mathbf{B}, \mathbf{D})$. Original magnification, $\times 100(\mathbf{A}, \mathbf{B})$, or $\times 400(\mathbf{C}, \mathbf{D})$. Note the conserved islet architecture and normal proliferative rate of both endocrine and exocrine tissues in $\mathrm{R}$ animals. Arrows indicate double positive cells lions cells at weaning (Fig. 1C). In $\mathrm{R}$ baby rats, this number was reduced by $20 \%$ at day 1 and by $36 \%$ at day 7 . From days 7 to 21 , beta-cell number did not increase in this group, leaving the animals with three times fewer beta-cells than the controls at weaning. There are several mechanisms by which perinatal malnutrition can induce a decrease in beta-cell number, one of which being a decreased beta-cell proliferation rate. This was measured after in vivo incorporation of BrdU.

At each time point, the beta-cell BrdU labelling index was not different between control and $\mathrm{R}$ rats (Table 1, Fig. 2) and this result was confirmed by the finding of similar beta-cell number per sectioned islet

Table 1. Comparative analysis of beta-cell morphometrical parameters in control $(\mathrm{C})$ and restricted (R) animals during the undernutrition period

\begin{tabular}{|c|c|c|c|c|}
\hline \multirow[t]{2}{*}{ Group } & \multicolumn{2}{|l|}{ Day 7} & \multicolumn{2}{|l|}{ Day 21} \\
\hline & $\mathrm{C}$ & $\mathrm{R}$ & $\mathrm{C}$ & $\mathrm{R}$ \\
\hline Body weight (g) & $15.6 \pm 0.8$ & $12.7 \pm 0.4 * * *$ & $54.9 \pm 3.2$ & $27.4 \pm 1.6^{* * *}$ \\
\hline Pancreas weight (mg) & $51.7 \pm 5.3$ & $40.1 \pm 6.5^{*}$ & $228.2 \pm 20.9$ & $98.7 \pm 21.3^{* * *}$ \\
\hline beta-cell mass/body weight (ng/g) & $117.3 \pm 13.8$ & $79.5 \pm 8.1 * * *$ & $50.4 \pm 6.1$ & $31.5 \pm 6.9 * *$ \\
\hline Individual beta-cell area $\left(\mu \mathrm{m}^{2}\right)$ & $99 \pm 17$ & $91 \pm 17$ & $101 \pm 20$ & $88 \pm 17$ \\
\hline beta-cell labelling index (\%) & $2.73 \pm 0.58$ & $2.69 \pm 0.29$ & $1.22 \pm 0.17$ & $1.29 \pm 0.28$ \\
\hline Insulin positive aggregates $/ \mathrm{cm}^{2}$ & $1024 \pm 87$ & $917 \pm 144$ & $357 \pm 53$ & $333 \pm 50$ \\
\hline
\end{tabular}

All values are mean \pm S.D of 5 different animals in each group. The number of insulin positive aggregates $/ \mathrm{cm}^{2}$ is also referred to in the text as number of islets $/ \mathrm{cm}^{2}$.

$* * * p \leq 0.001, * * p \leq 0.01, * p<0.05$, compared with controls 
Table 2. Comparative analysis of beta-cell morphometrical parameters in the head and the tail of 3-month-old rat pancreata

\begin{tabular}{lll}
\hline Group & $\mathrm{C}$ & $\mathrm{R}$ \\
\hline body weight (g) & $453.8 \pm 41.0$ & $372.7 \pm 26.8^{* *}$ \\
pancreas weight (g) & $1.28 \pm 0.11$ & $1.50 \pm 0.06^{* *}$ \\
beta-cell fraction (head, \%) & $0.51 \pm 0.15$ & $0.25 \pm 0.07^{* *}$ \\
beta-cell fraction (tail, \% ) & $0.55 \pm 0.07$ & $0.43 \pm 0.06^{*}$ \\
mean beta-cell fraction (\%) & $0.54 \pm 0.09$ & $0.36 \pm 0.06^{* *}$ \\
beta-cell mass (mg) & $6.73 \pm 0.88$ & $5.35 \pm 0.79^{*}$ \\
beta-cell mass/body weight (ng/g) & $14.9 \pm 2.6$ & $14.2 \pm 1.9$ \\
beta-cell labelling index (head, \%) & $0.47 \pm 0.06$ & $0.55 \pm 0.06$ \\
beta-cell labelling index (tail, \%) & $0.46 \pm 0.07$ & $0.63 \pm 0.07^{* *}$ \\
mean beta-cell labelling index (\%) & $0.47 \pm 0.06$ & $0.61 \pm 0.05^{* *}$ \\
Insulin positive cell aggregates/cm & $122 \pm 21$ & $80 \pm 10^{* *}$ \\
\hline All & &
\end{tabular}

All values are mean \pm S. D of 5 different control $(C)$ and restricted $(\mathrm{R})$ animals

$* * p \leq 0.01, * p<0.05$ : compared with controls

(Table 1), suggesting that early postnatal malnutrition did not alter the capacity of beta cells to proliferate. These findings thus raised the possibility of a defect in differentiation, another process involved in the expansion of beta-cell mass during the perinatal period. The number of aggregates $/ \mathrm{cm}^{2}$ composed of more than three insulin-positive cells and reflecting the islet number was slightly decreased at day 7 but similar to controls at day 21 . This result, together with the similar beta-cell number per sectioned islet and the smaller pancreatic weight, suggests that the overall decrease in beta-cell mass and number per pancreas at weaning is likely to arise from a decrease in the total number of islets of similar size. No disruption of islet architecture was observed at any stage studied in the $\mathrm{R}$ baby rats (Fig. 2).

Consequences at adulthood of early malnutrition. Ad libitum feeding from weaning did not restore body weight (Table 2). Fasting glycaemia was similar in R: $72.2 \pm 6.2$ compared with $70.6 \pm 5.2 \mathrm{mg} / \mathrm{dl}$ in control animals $(p=0.49, n=12)$, whereas fasting insulinaemia was slightly decreased: $2.37 \pm 0.51$ compared with $3.07 \pm 0.93 \mathrm{ng} / \mathrm{ml}(p=0.02, n=12)$.

The possible permanent impairment of beta cells was investigated at adulthood ( 3 months of age) in the $\mathrm{R}$ animals given a normal food supply from weaning. In these animals, mean beta-cell fraction was decreased by $35 \%$, as compared with controls (Fig. 1A and Table 2). At this age, absolute beta-cell mass per pancreas and beta-cell number were decreased by $20 \%$ in previously restricted $\mathrm{R}$ animals (Fig. 1B-1C, Table 2).

In control animals, beta-cell fraction was similar in the head and the tail of the pancreas (Table 2). It differed markedly, however, in $\mathrm{R}$ animals, in which the overall decrease in beta-cell fraction compared with controls derived mainly from a $50 \%$ decrease in the head of the pancreas (Table 2).

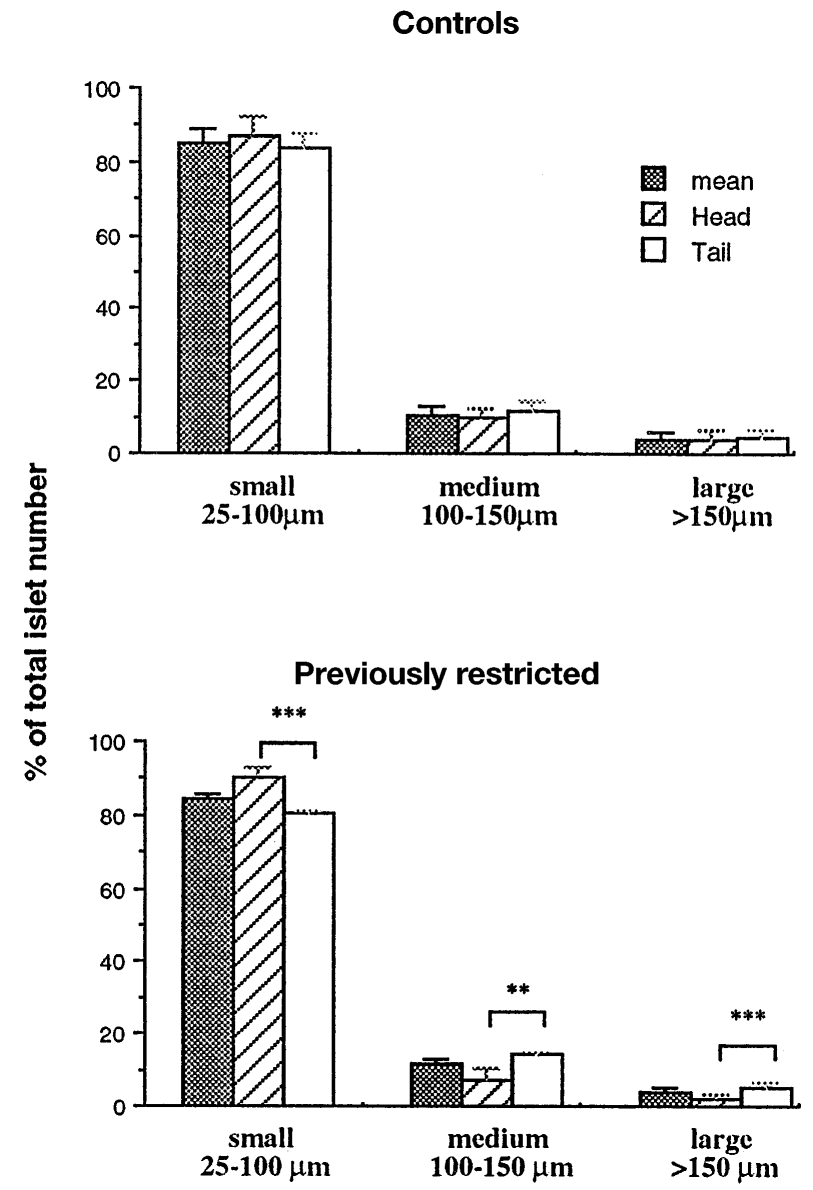

Fig. 3. Relative distribution of islet size in the head and the tail of pancreas from adult animals

The total islet number per section (as defined previously in Materials and methods) was counted and islets were classified as small (25-100 $\mu \mathrm{m}$ diameter), medium (100-150 $\mu \mathrm{m})$ or large $(>150 \mu \mathrm{m})$. The comparative distribution of islet size in the head (hatched bars) and in the tail (open bars) of pancreas from control (top panel) and R (bottom panel) adult animals is expressed in each class as a percentage of total islet number. Mean values per pancreas (grey bars) were calculated from all head and tail section values for each animal and averaged thereafter for each experimental group, as described in Materials and methods. All data are mean \pm SD

The BrdU labelling index measured in acinar cells showed a fourfold increase $(6.09 \pm 0.35 \%)$, as compared with controls $(1.61 \pm 0.29 \%, \mathrm{p}<0.0001)$, showing important proliferative activity in this particular cell area. In the beta cells, BrdU labelling index was increased by $30 \%$ in $\mathrm{R}$ animals and this increase was most pronounced $(37 \%)$ in the tail of the pancreas (Table 2). In line with these regional variations, the relative distribution of islet size varied between the head and tail of the pancreas in $\mathrm{R}$ animals. There were more islets of median $(100-150 \mu \mathrm{m})$ and large $(>150 \mu \mathrm{m})$ size and less islets of small size $(25-100 \mu \mathrm{m})$ in the tail than in the head of the pancreas in these animals (Fig. 3). No regional variations in the relative distribution of islet size or in the beta- 
cell labelling index were observed in control animals (Fig. 3 and Table 2, respectively). Furthermore, a $35 \%$ decrease in the number of insulin-positive aggregates per $\mathrm{cm}^{2}$ was observed both in the head and tail of the pancreas in previously restricted animals, as compared with controls (Table 2).

\section{Discussion}

This study shows that prolonged maternal under nutrition during lactation severely impairs beta-cell development in the offspring. The normal BrdU labelling index in the beta cells until weaning suggests that malnutrition did not alter beta-cell proliferation rate. Subsequent re-nutrition is followed by a rapid catch-up in both exocrine and endocrine pancreatic mass which results from increased exocrine and beta-cell proliferation, but this is insufficient to fully restore beta-cell mass in adult animals.

Postnatal under-nutrition decreased the proportion of beta cells within the pancreas at all stages studied, extending our previous observations at birth [7]. Due to the dramatic stunting of overall pancreatic growth, the reduction in beta-cell mass was severe at the end of the malnutrition period since during the first 3 weeks of postnatal life in contrast to the threefold increase of beta-cell mass in normal rats, almost no increment was observed. This reduction was mainly due to a decrease in beta-cell number rather than a reduction of individual beta-cell size. Whereas the observed diminution of the beta-cell fraction is similar to that described recently in 4-day-old rats given a $65 \%$ food restriction during fetal and postnatal life [8], the reduction already present at birth is in contrast to the increased beta-cell fraction and mass described by the same group in 21-day-old fetuses [15]. We have no explanation for the contrasting effect of undernutrition within such a short time period, further investigations on both animal models are required to fully and accurately explain the contrast.

Two major processes are generally considered to be responsible for beta-cell mass expansion: differentiation of precursor cells of ductal origin, a process also termed neogenesis, and proliferation of pre-existing beta cells. To further investigate the mechanism underlying the alteration in beta-cell mass, we have measured the labelling index of beta cells after incorporation of BrdU in vivo. The similar BrdU labelling index in control and restricted animals, together with the finding of similar beta-cell number per sectioned islet, show that the remaining beta cells have retained their capacity to proliferate during the malnutrition period. This result was rather unexpected in view of the well documented growth-promoting effect of glucose, amino acids and growth factors such as insulin-like growth factors or growth hormone [16-18] which are likely to be decreased in malnour- ished rats [19-22]. The normal islet number per $\mathrm{cm}^{2}$ in restricted animals with a pancreas weight half that of control animals at weaning suggests that a reduction in total islet number occurs in malnourished weanlings. Thus the impairment of islet neogenesis already shown at birth is likely to be amplified when malnutrition is prolonged postnatally. Although the beta-cell proliferation rate was normal from birth to weaning in restricted animals, there was almost no increase in beta-cell mass or number during this period. This finding could be due to accelerated beta-cell death as a result of competition for a limited supply of nutrients or growth factors [23]. Indeed a wave of beta-cell death with an increased number of apoptotic nuclei has recently been described in normal rat pancreas in the neonatal period shortly before weaning $[14,24,25]$. Preliminary results suggest increased apoptosis in the beta cells during the malnutrition period.

Animals with severe growth retardation at birth which had been malnourished until weaning displayed irreversible growth retardation [9] but the pancreatic weight/body weight ratio increased, suggesting a striking catch-up in exocrine pancreatic growth, that was confirmed by the fourfold increase of BrdU incorporation in acinar cells. These animals displayed irreversible, although moderate, impairment of absolute beta-cell mass and number, in the range of the previously described reduction in total insulin content per pancreas [9], suggesting that insulin content per cell is likely to be preserved in malnourished animals (around $7 \mathrm{pg}$ of insulin per beta cell at birth, $15 \mathrm{pg}$ at weaning and $45 \mathrm{pg}$ at 3 months of age, values in accordance with literature) [26-28]. Although the beta-cell mass/body weight ratio was in the normal range at adulthood and might contribute to the maintenance of normoglycaemia, fasting insulin concentrations were slightly decreased, suggesting a possible defect in the secretory capacity. Surprisingly, overall beta-cell proliferation was significantly increased during the re-nutrition period and this increase was more pronounced in the tail of the pancreas, together with a shift of islet size distribution towards larger islets. The number of insulin-positive cell aggregates per $\mathrm{cm}^{2}$, reflecting the islet number per $\mathrm{cm}^{2}$, was also decreased by $35 \%$ both in the head and tail. Thus, the partial recovery of beta cells observed in this study arises, at least in part, from increased beta-cell proliferation, occurring essentially in the tail. It cannot be excluded, however, that increased neogenesis or decreased apoptosis or both also contributed to the recovery. The reasons for this selective and regional variations are not known. The impact of the topographical distribution of the various islet cell types within the islets and within the different regions of the pancreas, should also be considered [29]. Indeed the tail part of the pancreas corresponded to a glucagon-rich and PP-poor region, 
whereas the head part contained fivefold more PP and fewer glucagon cells, both in control and $\mathrm{R}$ animals. The selective regeneration in the tail could also be linked to a preferential local increase in stimulating factors. Finally, regional modifications in the vascular area could also be relevant since alterations in the vascularization of the endocrine pancreas have been described in rat neonates whose mothers were given a low-protein diet [6] as well as in adults, consecutive to a life-long low-protein diet [30].

The ability of both exocrine and endocrine pancreas to respectively, fully or partly, regenerate after renutrition through increased cell proliferation further documents the plasticity of the pancreas already shown in adult animals after duct ligation, cellophane wrapping or subtotal pancreatectomy [31]. In most reports a stimulation of both islet-cell proliferation and neoformation of islets from the ducts has been shown [32-34]. Although this last phenomenon has not been quantified in our model, the presence of a number of islets around the ducts in control as well as in $\mathrm{R}$ animals, suggests local signals must exist which are potentially capable of promoting postnatal growth in the previously restricted animals.

Acknowledgements. The authors wish to thank N Tabti, DJ Hill and P Gressens for constructive comments. This work was funded by the Institut National de la Santé et de la Recherche Médicale (INSERM) and a grant from the Fondation pour la Recherche Médicale. We also thank Novo Laboratories for financial support to A. G.

\section{References}

1. Hales C, Barker D, Clark P et al. (1991) Fetal and infant growth and impaired glucose tolerance at age 64. BMJ 303: 1019-1022

2. Phillips D, Barker D, Hales C, Hirst S, Osmond C (1994) Thinness at birth and insulin resistance in adult life. Diabetologia 37: 150-154

3. Lithell H, McKeigue P, Berglund L, Mohsen R, Lithell U, Leon D (1996) Relation of size at birth to non-insulin dependent diabetes and insulin concentrations in men aged 50-60 years. BMJ 312: 406-410

4. Hellerström C, Swenne I (1985) Growth pattern of pancreatic islets in animals. In: Volk B, Arquilla E (eds) The diabetic pancreas. Plenum, Press, New York, pp 53-79

5. Swenne I, Borg L, Crace C, Landström AS (1992) Persistent reduction of pancreatic Beta-cell mass after a limited period of proteinenergy malnutrition in the young rat. Diabetologia 35: 939-945

6. Snoeck A, Remacle C, Reusens B, Hoet J (1990) Effect of a low protein diet during pregnancy on the fetal rat endocrine pancreas. Biol Neonate 57: 107-118

7. Garofano A, Czernichow P, Bréant B (1997) In utero undernutrition impairs rat beta-cell development. Diabetologia 40: 1231-1234

8. Martin A, Alvarez C, Goya L, Portha B, Pascual-leone A (1997) Insulin secretion in adult rats that had experienced different underfeeding patterns during their development. Am J Physiol 272:E634-E640

9. Garofano A, Czernichow P, Bréant B (1998) Postnatal somatic growth and insulin contents in moderate or severe intra-uterine growth retardation. Biol Neonate 73: 89-98

10. Wang R, Bouwens L, Klöppel G (1994) Beta-cell proliferation in normal and streptozotocin-treated newborn rats: site, dynamics and capacity. Diabetologia 37: 1088-1096

11. Buitrago A, Gylfe E, Henriksson C, Pertoft H (1977) Rapid isolation of pancreatic islets from collagenase digested pancreas by sedimentation through percoll at unit gravity. Biochem Biophys Res Commun 79: 823-828

12. Bonner-Weir S (1994) Regulation of pancreatic $\beta$ cell mass in vivo. Recent Prog Horm Res 49: 91-104

13. Pipeleers D (1987) The biosociology of the pancreatic ß-cell. Diabetologia 30: 277-291

14. Finegood D, Scaglia L, Bonner-Weir S (1995) Dynamics of $\beta$-cell mass in the growing rat pancreas. Estimation with a simple mathematical model. Diabetes 44: 249-256

15. Alvarez C, Martin M, Goya L, Bertin E, Portha B, Pascual-Leone A (1997) Contrasted impact of maternal rat food restriction on the fetal endocrine pancreas. Endocrinology 138: 2267-2273

16. Swenne I, Hill D, Strain A, Milner R (1987) Growth Hormone regulation of somatomedin $\mathrm{C} /$ Insulin-like Growth factor I production and DNA replication in fetal rat islets in tissue culture. Diabetes 36: 288-294

17. Bonner-Weir S, Deery D, Leahy J, Weir G (1989) Compensatory growth of pancreatic B-cells in adult rats after short-term glucose infusion. Diabetes 38: 49-53

18. Swenne I (1983) Effects of aging on the regenerative capacity of the pancreatic B-cell of the rat. Diabetes 32: 14-19

19. Woodall S, Breier B, Johnston B, Gluckman P (1996) A model of intrauterine growth retardation caused by chronic maternal undernutrition in the rat: effects on the somatotrophic axis and postnatal growth. J Endocrinol 150: 231-242

20. Oster M, Fielder P, Lewin N, Cronin M (1995) Adaptation of the growth-hormone and insulin-like growth factor-1 axis to chronic and severe calorie or protein malnutrition. J Clin Invest 95: 2258-2265

21. Owens J (1991) Endocrine and substrate control of fetal growth: placental and maternal influences and insulin-like growth factors. Reprod Fertil Dev 3: 501-517

22. Rivero F, Goya L, Alvarez C, Pascual-Leone A (1995) Effect of undernutrition and diabetes on serum and liver mRNA expression of IGFs and their binding proteins during rat development. J Endocrinol 145: 427-440

23. Coles H, Burne J, Raff M (1993) Large-scale normal cell death in the developing rat kidney and its reduction by epidermal growth factor. Development 118: 777-784

24. Scaglia L, Cahill C, Finegood D, Bonner-Weir S (1997) Apoptosis participates in the remodeling of the endocrine pancreas in the neonatal rat. Endocrinology 138: 1736-1741

25. Hill D, Petrik J, Arany E (1997) Insulin-like growth factors in the development of the pancreas. Exp Clin Endocrinol Diabetes 105: A30-A31

26. McEvoy R (1981) Changes in the volumes of the A-, B-, and D-cell populations in the pancreatic islets during the postnatal development of the rat. Diabetes 30: 813-817

27. Freie H, Pasma A, Bouman P (1975) Quantitative analysis of pancreatic islet development and insulin storage in the foetal and newborn rat. Acta Endocrinologica 80: 657-666

28. McEvoy R, Madson K (1980) Pancreatic insulin-, glucagon-, and somatostatine-positive islet cell populations during the perinatal development of the rat. II. Changes in hormone content and concentration. Biol Neonate 38: 255-259

29. Orci L (1976) The microanatomy of the islet of Langerhans. Metabolism 25: 1303-1309

30. Iglesias-Barreira V, Ahn M, Reusens B, Dahri S, Hoet J, Remacle C (1996) Pre- and postnatal low protein diet affect pancreatic islet blood flow and insulin release in adult rats. Endocrinology 137: 3797-3801

31. Slack J (1995) Developmental biology of the pancreas. Development 121: $1569-1580$

32. Wang R, Klöppel G, Bouwens L (1995) Duct-to islet-cell differentiation and islet growth in the pancreas of duct-ligated adult rats. Diabetologia 38: 1405-1411

33. Smith F, Rosen K, Villa-Komaroff L, Weir G, Bonner-Weir S (1991) Enhanced insulin-like growth factor I gene expression in regenerating rat pancreas. Proc Natl Acad Sci USA 88: 6152-6156

34. Rosenberg L, Brown R, Duguid W (1983) A new approach to the induction of duct cell epithelial hyperplasia and nesidioblastosis by cellophane wrapping of the hamster pancreas. J Surg Res 35: 63-72 